\title{
Zuriah
}

Volume 1, Nomor 1, 2020

Jurnal Pendidikan Anak Usia Dini ISSN 2746-0797 (p), 2746-0800 (e)

http://journal.iaincurup.ac.id/index.php/paud DOI: http://dx.doi.org/10.29240/zuriah.v1i1.1884

\section{Peran Orang Tua di Era Digital}

H.M. Taufik Amrillah

IAIN Curup

taufikamrillah@iaincurup.ac.id

\section{Amanah Rahmaningtyas \\ IAIN Curup \\ amanahrahmaningtyas@iaincurup.ac.id}

\author{
Meri Hartati \\ IAIN Curup \\ merihartati@iaincurup.ac.id \\ Gladis Agustin \\ IAIN Curup \\ gladisagustin@iaincuru.ac.id
}

\begin{abstract}
This article discusses the role of parents in the digital age. The digital Era is characterized by the presence of technology, where there is an increase in the speed and flow of knowledge turnover in the economy and community life. Parents who are part of the information society cannot avoid that children in the digital age never escape from objects related to technology. The increase of digital technology in children's developmental life invaded many development phases that the child should achieve. Technology makes their lives faster (instant) and more efficient. Entertainment technologies such as television, internet, video games, iPod, iPad, and others have grown so rapidly that it makes a family hardly aware of the significant impact and lifestyle changes in their families. The education undertaken anciently differed from today's education. As new knowledge and technologies and cultural shifts are caused by thought patterns that are influenced by information obtained in a very easy way. It is demanding that parents always update / upgrade their knowledge in order to give direction to their children in a wise way. Parents need to accompany to avoid unwanted things so that the concern of parents and educators of early childhood in the digital age is the importance of the introduction of religious values, local wisdom, so as to fortify the child from global influences.
\end{abstract}

Key words: Early childhood, Parents, Digital Era.

23| ZURIAH : Jurnal Pendidikan Anak Usia Dini, Vol. 1 No. 1, Mei 2020 


\begin{abstract}
Abstrak
Tulisan ini membahas tentang peran orang tua di era digital. Era digital ditandai dengan adanya teknologi, di mana terjadi peningkatan pada kecepatan dan arus pergantian pengetahuan dalam ekonomi dan kehidupan masyarakat. Orang tua yang merupakan bagian dari masyarakat informasi tidak dapat mengelak bahwa anak-anak di era digital tak pernah lepas dari benda-benda yang berbubungan dengan teknologi. Meningkatnya teknologi digital dalam kehidupan perkembangan anak menginvasi banyak tahapan perkembangan yang harusnya dicapai anak. Teknologi membuat bidup mereka lebih cepat (instan) dan lebih efisien. Teknologi hiburan seperti televisi, internet, video game, iPod, iPad, dan lainnya telah berkembang begitu pesat sehingga membuat suatu keluarga hampir tidak menyadari dampak signifikan dan perubahan gaya bidup pada keluarga mereka. Pendidikan yang dilakukan pada zaman dabulu berbeda dengan pendidikan pada zaman sekarang. Seiring bertambahnya pengetahuan dan teknologi baru serta pergeseran budaya yang disebabkan oleh pola fikir yang dipengarubi informasi yang didapatkan dengan cara yang sangat mudah. Hal ini menuntut orang tua agar selalu meng-update/ upgrade pengetahuanny agar bisa memberikan arahan kepada anaknya dengan cara yang bijak. Orang tua perlu melakukan pendampingan untuk. menghindari hal yang tidak dïnginkan sehingga hal menjadi perhatian orang tua dan pendidik anak usia dini di era digital adalah pentingnya pengenalan nilai-nilai agama, kearifan lokal, sehingga mampu membentengi anak dari pengaruh global.
\end{abstract}

Kata Kunci: Anak usia dini , Orang tua, Era digital.

\title{
A. PENDAHULUAN
}

Era digital merupakan istilah yang digunakan dalam kemunculan digital, jaringan internet, atau lebih khusus lagi teknologi informasi. Era digital ditandai dengan adanya teknologi, di mana terjadi peningkatan pada kecepatan dan arus pergantian pengetahuan dalam ekonomi dan kehidupan masyarakat. Orang tua yang merupakan bagian dari masyarakat informasi tidak dapat mengelak bahwa anak-anak di era digital tak pernah lepas dari benda-benda yang berhubungan dengan teknologi. Teknologi baru adalah salah satu indikator yang paling terlihat dari munculnya zaman baru, dan juga untuk menandakan kedatangan masyarakat informasi. Revolusi teknologi informasi menyebabkan tersebarnya teknologi komunikasi dan hal tersebutlah yang dapat menginsiprasi terciptanya masyarakat baru (Webster, 2006).

Sejalan dengan kemajuan teknologi, maka ada dampak yang muncul di tengah kehidupan masyarakat. Banyak perubahan yang terjadi pada masyarakat baik itu dari segi 
sosial, ekonomi, politik dan hampir semua aspek kehidupan bisa dipengaruhi oleh perubahan teknologi. Salah satunya yang terdampak oleh kemajuan teknologi adalah pendidikan pada usia dini. Usia dini adalah masa emas perkembangan sekaligus masa kritis anak. Pada masa ini seluruh aspek perkembangan anak sedang berkembang sangat pesat. Masa usia dini merupakan merupakan masa terpenting dalam rentang kehidupan seseorang karena pada masa ini terjadi proses pertumbuhan dan perkembangan yang sangat cepat. Direktorat pembinaan pendidikan anak usia dini (2015) memberikan definisi menurut ahli neurosain masa usia dini merupakan masa pembentukan jaringan sel otak dan terjadinya sangat cepat. Kecepatan ini tidak terjadi pada masa berikutnya. Baik itu dilihat dari segi pertumbuhan serta perkembangan anak pada masa ini terjadi sangatlah cepat. Waktunya sangat kritis, yaitu sejak lahir sampai dengan usia 6 tahun. Penting bagi para orang tua untuk memanfaatkan masa emas ini dengan baik agar tidak hilang dan terlewat. Keberhasilan selama periode ini akan menentukan keberhasilan anak dalam kehidupan selanjutnya hingga dewasa.

Perhatian pemerintah terhadap pendidikan anak memang harus digencarkan sebab anak adalah investasi bangsa Indonesia di masa depan. Perlunya perhatian serius pada pendidikan anak merupakan kewajiban kita semua khususnya orang tua. Sebab, keunikan pada perlakuan pendidikan anak sangat berbeda dengan pendidikan orang dewasa. Dunia anak adalah dunia main yang penuh dengan fantasi dan hal yang baru. Selain itu, jiwa yang selalu ingin tau (curiously) harus diatur dengan baik agar tahapan pendidikan pada anak sesuai dengan pertumbuhan mental anak.

Indonesia merupakan negara yang sedang mengalami dinamika dan perkembangan globalisasi yang sangat signifikan. Kondisi tersebut menjadi bagian yang tidak terpisahkan dalam kehidupan seorang anak. Hal itu ditandai dengan derasnya arus informasi, komunikasi, serta semakin menjamurnya teknologi dan modernisasi di segala bidang kehidupan. Globalisasi yang dirasakan saat ini berdampak terhadap dunia pendidikan, termasuk dalam pendidikan anak. Anak merupakan harapan bangsa dan negara yang menjadi tumpuan segenap bangsa Indonesia. Oleh karena itu,anak harus mendapatkan perhatian dan pendidikan sejak usia dini. Hal ini pada hakikatnya bahwa pendidikan anak merupakan hak dasar untuk memperoleh pendidikan, sehingga menjadi modal utama untuk menyiapkan anak yang berkualitas yang berkembang secara optimal baik fisik maupun psikis. Sehingga diharapkan pendidikan pada anak usia

ZURIAH : Jumnal Pendidikan Annak Usia Dini, Vol. 1 No. 1, Meś 2020| 25 
dini dapat menjadi landasan dan pijakan bahwa pentingnya pendidikan anak usia dini era globalisasi saat ini.

Pesatnya perkembangan teknologi informasi di era sekarang ini membawa banyak dampak bagi dunia pendidikan anak usia dini, baik itu berupa dampak positif serta negatif. Maka dari itu diperlukan peran seluruh stakeholder yang berkontribusi dalam dunia pendidikan anak usia dini dalam menyikapi era sekarang ini. Terutama bagi orang tua yang memang banyak menghabiskan waktunya bersama dengan anak. Orang tua dituntut untuk menjadi orang tua yang cermat dalam menggunakan teknologi informasi bagi kehidupan anaknya. Karena dampak yang ditimbulkan sangatlah luar biasa bagi perkembangan anak usia dini. Segala aspek perkembangan dapat dipengaruhi oleh pola asuh orang tua.

\section{B. PEMBAHASAN}

1. Peran Orang Tua dalam Pendidikan Anak Usia Dini

Anak adalah 'Peniru Ulung'. Sikap mereka di sekolah, di lingkungan dan masyarakat adalah cerminan bagaimana kehidupan mereka di rumah, yang tentu tidak terlepas dari didikan orang tuanya. Rumah merupakan madrasah (sekolah) pertama bagi tumbuh kembang anak dan orang tua adalah guru utama bagi tahun-tahun pertama kehidupan mereka. Disebabkan karena usia dini adalah usia meniru, maka orang tua adalah 'model' bagi anaknya. Oleh karena itu, keluarga menjadi ujung tombak dalam perkembangannya.

Keluarga merupakan pendidik utama bagi anak usia dini. Tetapi bagaimanapun pendidikan yang diberikan oleh orang tua di dalam sebuah keluarga masih ada keterbatasan dalam mendidik anak usia dini. Oleh karena itu memasukkan anak ke Pendidikan Anak Usia Dini (PAUD) sangatlah tepat. Belajar melalui bermain yang dilakukan di PAUD sangat mendukung semua aspek perkembangan anak.

Jika pengasuhan anak di keluarga berjalan dengan baik dan selaras dengan yang dilakukan di PAUD maka semua aspek perkembangan anak akan bisa berkembang secara optimal. Pada akhirnya perkembangan ini akan menyumbang pada kemampuan anak berpikir logis, kritis, dan kreatif serta mampu berkomunikasi dan bekerjasama. Kemampuan-kemampuan itu sangat diperlukan anak di masa-masa kehidupan selanjutnya dalam menghadapi tantangan hidup yang semakin beragam.

Agar pendidikan yang dilaksanakan di dalam keluarga sejalan dengan apa yang dilaksanakan di sekolah. Orang tua diminta untuk aktif dalam kegiatan yang 
diselenggarakan oleh pihak sekolah mengenai program yang terkait dengan orang tua. Hal ini ditujukan agar orang tua memahami program-program pendidikan yang dilakukan di sekolah sehingga apa yang diajarkan di rumah selaras dengan apa yang didapatkan anak di lembaga pendidikan.

Berdasarkan uraian tersebut, dapat dipahami bahwa pendidikan anak usia dini menjadi bagian penting dalam kehidupan seseorang terutama bagi orang tua dan para pendidik untuk lebih aktif dalam mengembangkan dan menumbuhkan stimulasi anak baik secara kuantitatif maupun kualitatif. Sehingga orang tua dan para pendidik, pengasuh anak dengan rasa senang melakukan proses pendidikan anak sejak dini dengan melakukan aktivitas permainan yang dapat mengembangkan kemampuan otak anak, serta melatih anak untuk dapat membentengi dari pengaruh globalisasi. Oleh karena itu, saatnya konsep mementingkan kembali pendidikan anak usia dini untuk dapat dijadikan sebagai wahana pengembangan anak usia dini, khususnya dalam memfilterisasi pengaruh global.

Sementara itu, Bredecamp menjelaskan bahwa Anak usia dini bersifat unik, mengekpresikan perilakunya secara relatif spontan, bersifat aktif dan energik, anak bersifat egosentris, memiliki rasa ingin tahu yang kuat dan antusias terhadap banyak hal, bersifat eksploratif dan berjiwa petualang, kaya dengan fantasi, masih mudah frustasi, kurang pertimbangan dalam bertindak, memiliki daya perhatian yang pendek, merupakan masa belajar yang paling potensial, semakin menunjukan minat terhadap teman (Masitoh, 2007). Hal lain yang di lakukan oleh anak adalah dengan cara berekplorasi dan berimajinasi. Aktivitas ekplorasi dan imajinasi anak menjadi salah satu ciri karakteristik anak usia dini. Oleh karena itu, pada anak usia dini menjadi bagian penting dalam memunculkan kemampuan anak dalam mengembangkan kemampuan kognitif anak secara optimal. Bermain menjadi ciri khas anak dalam mengembangkan kemampuan dirinya melalui kegiatan bermain peran dan bermain kelompok.

Setiap anak adalah unik. Mereka mempunyai kecerdasan yang berbeda-beda serta mengalami proses tumbuh kembang berbeda pula. Tetapi anak usia dini memiliki ciri khusus yang mana hampir semua anak mengalami dan memiliki ciri ini di antaranya yaitu berimajinasi, bernyanyi, aktif bergerak, mencoba hal baru, selalu bertanya tentang sesuatu yang dia belum ketahui. Untuk melakukan segala 
karakteristik anak yang telah disebutkan tadi, anak membutuhkan sarana baik itu di lingkungan keluarga maupun di lembaga pendidikan dimana anak dititipkan.

Pendidikan anak usia dini merupakan salah satu bentuk penyelenggaraan pendidikan yang menitikberatkan pada peletakan dasar ke arah pertumbuhan dan perkembangan fisik (koordinasi motorik halus dan kasar), kecerdasan (daya pikir, daya cipta, kecerdasan emosi, kecerdasan spiritual), sosio emosional (sikap dan perilaku serta agama) bahasa dan komunikasi, sesuai dengan keunikan dan tahaptahap perkembangan yang dilalui oleh anak usia dini.

Perkembangan secara optimal hanya bisa terwujud jika dilakukan upaya pembinaan yang terencana, holistik, intensif, didasarkan pada karakteristik perkembangan. Upaya pembinaan yang ditujukan kepada anak sejak lahir sampai dengan usia 6 tahun yang dilakukan melalui pemberian rangsangan pendidikan untuk membantu pertumbuhan dan perkembangan jasmani dan rohani agar anak memiliki kesiapan dalam memasuki pendidikan lebih lanjut disebut sebagai pendidikan anak usia dini atau lebih dikenal dengan PAUD (Sujiono, 2009).

Dalam konteks pendidikan anak usia dini formal bermain pada dasarnya merupakan bagian integral dari lingkungan akademik. Hal ini membawa konsekuensi bahwa kegiatan bermain hendaknya dikelola dengan sebaik mungkin. Untuk keperluan tersebut pendidik hendaknya memperhatikan densitas dan intensitas bermain dengan didasarkan pada kebutuhan akan perkembangan anak. Densitas (density) adalah berbagai macam cara bermain yang disediakan untuk mendukung pengalaman anak dan intensitas (intensity) adalah sejumlah waktu yang dibutuhkan untuk bermain (Latif, 2013).

2. Pengaruh Teknologi Informasi Terhadap Anak Usia Dini

Teknologi digital menjadi satu aspek penting dalam faktor yang mempengaruhi perkembangan anak. Masuknya teknologi digital dalam kehidupan perkembangan anak menginvasi banyak tahapan perkembangan yang harusnya dicapai anak. Teknologi membuat hidup mereka lebih cepat (instan) dan lebih efisien. Teknologi hiburan seperti televisi, internet, video game, iPod, iPad, dan lainnya telah berkembang begitu pesat sehingga membuat suatu keluarga hampir tidak menyadari dampak signifikan dan perubahan gaya hidup pada keluarga mereka (Rowan, 2013).

ZURIAH : Jurnal Pendidikan Annak Usia Dini, Vol. 1 No. 1, Meś 2020| 28 
Salah satu penyebab anak usia dini bisa mengakses teknologi adalah melalui orangtuanya. Dengan berbagai macam alasan orang tua sehingga anak diberikan teknologi tersebut. Gaya hidup orang tua akan sangat mempengaruhi kehidupan anak yang diasuhnya. Rasa ingin tahu atau "penasaran” pada anak usia dini sangatlah tinggi, sehingga apapun yang dilakukan oleh orang tua mereka sangat ingin mengetahuinya.

Berdasarkan hasil penelitian yang dilakukan oleh The Asian Parent Insights pada November 2014, sebanyak 98 persen dari 2.714 orang tua di Asia Tenggara yang mengikuti penelitian ini mengizinkan anaknya untuk mengakses teknologi berupa komputer, smartphone, atau tablet. Penelitian ini dilakukan terhadap 2.714 orang tua di Asia Tenggara yang memiliki anak berusia 3 - 8 tahun. Para orang tua peserta penelitian ini berasal dari Singapura, Malaysia, Thailand, Indonesia, dan Filipina. Dari hasil survey tersebut kebanyakan orangtua memperbolehkan anaknya bermain gadget untuk tujuan edukasi. Namun kenyataannya menurut hasil survey sebagian besar putra-putri mereka menggunakan gadget/tablet tersebut untuk tujuan hiburan seperti game (Unantenne, 2014).

Terlebih lagi gadget merupakan hal yang sangat menarik bagi anak usia dini. Di sinilah orang tua terkadang memanfaatkan gadget sebagai pengganti peran dari pada orang tua. Hal tersebut merupakan hal yang instan dan mudah untuk diaplikasikan. Sebagai contoh, ketika anak menangis, hal yang paling mudah untuk membuat anak berhenti dari tangisnya yaitu dengan cara memberikan gadget. Contoh lain, ketika orang tua sibuk dengan pekerjaan rumah agar tidak diganggu oleh anaknya mereka menggunakan cara memberikan sang anak akses terhadap teknologi informasi dalam bentuk gadget.

Kini, waktu yang dihabiskan anak-anak dengan media setiap harinya lebih banyak. Waktu yang dihabiskan untuk menonton televisi rata-rata 3 jam di hari sekolah dan 7.4 jam pada hari libur, waktu bermain permainan elektronik 3.8 jam dan waktu dihabiskan untuk bermain internet rata-rata 2.1 jam. Data dari Nielsen Media menunjukkan bahwa satu dari setiap empat penonton televisi di Indonesia adalah anak, dan waktu yang dihabiskan anak-anak menonton televisi rata-rata tiga jam per hari (Hendriyani, dkk, 2012).

Kemajuan teknologi membawa berbagai macam dampak bagi anak usia dini, baik itu berupa dampak yang positif maupun negatif. Untuk dampak negative bagi

ZURIAH : Jumnal Pendidikan Anaks Usia Dini, Vol. 1 No. 1, Mer $2020 \mid 29$ 
anak yaitu anak bisa menambah wawasan dengan menggunakan teknologi yang ada didepannya, tentu saja hal tersebut harus dengan pengarahan oleh orang dewasa sekitarnya. Dengan menggunakan gadget yang sangat mudah didapatkan oleh anak sekarang, anak bisa banyak belajar dengan cara yang menyenangkan. Dikarenakan banyak sekali aplikasi, lagu, video yang berhubungan dengan dunia pendidikan yang bisa digunakan untuk anak untuk belajar dengan tampilan yang sangat menarik bagi anak. Hal tersebut juga bisa dijadikan sebagai solusi bagi anak yang susah untuk diajak belajar dikarenakan kebosanan. Selain itu, hal tersebut juga bisa membuat anak terbiasa menggunakan teknologi dan menghindari menjadi manusia yang gagap dalam menggunakan teknologi.

Dari uraian di atas, bisa dikatakan bahwa teknologi memang banyak memberikan manfaat bagi kehidupan manusia, terutama bagi pendidikan anak usia dini. Walaupun demikian, teknologi juga membawa dampak yang positif apabila penggunaannya tidak dilakukan dengan cara yang bijak. Terutama bagi anak usia dini, dampak yang ditimbulkan sangat berbahaya. Mereka bisa menghabiskan banyak waktunya.

\section{Peran Orang Tua di Era Digital}

Salah satu tugas keluarga adalah memberikan pendidikan kepada anaknya sesuai pada zamannya. Pada era tahun 90an anak-anak bermain diluar rumah berinteraksi dengan teman sebayanya sedang asyik bermain permainan tradisional. Permainan tradisional nusantara menurut penelitian mendidik anak untuk jujur, kerjasama tim, percaya diri, dan amanah. Hal tersebut sangat cocok dengan pertumbuhan mental anak yang harus ditananamkan nilai-nilai moral. Selain itu, lagulagu anak sudah jarang dinyanyikan anak zaman sekarang. Padahal lagu anak adalah metode efektif dalam pendidikan karakter dengan syair-syair yang disesuaikan psikologi anak.

Tentu saja pendidikan yang dilakukan pada zaman dahulu berbeda dengan pendidikan pada zaman sekarang. Seiring bertambahnya pengetahuan dan teknologi baru serta pergeseran budaya yang disebabkan oleh pola fikir yang dipengaruhi informasi yang didapatkan dengan cara yang sangat mudah. Hal ini menuntut orang tua agar selalu meng-update/upgrade pengetahuannya agar bisa memberikan arahan kepada anaknya dengan cara yang bijak.

ZURIAH : Jumnal Pendidikan Anaks Usia Dini, Vol. 1 No. 1, Mer 2020 | 30 
Pengasuhan yang dilakukan orang tua durasi waktunya lebih panjang dari pada pengasuhan yang dilakukan oleh pendidik PAUD. Dunia digital yang sedang dihadapi oleh anak usia dini pada saat ini tidak mungkin bisa dihindari. Karena bagaimanapun hal tersebut sudah menjadi kebutuhan bagi kehidupan masyarakat pada umumnya. Keluarga adalah kelompok primer yang paling penting di dalam masyarakat. Keluarga merupakan sebuah kelompok yang terbentuk dari hubungan antara laki-laki dan perempuan yang berlangsung lama untuk menciptakan dan membesarkan anak. Jadi keluarga dalam bentuk murni merupakan satu kesatuan sosial yang terdiri dari suami, istri dan anak-anak.

Keluarga merupakan lingkungan terdekat bagi anak sejak anak dilahirkan. Di dalam keluarga anak memperoleh banyak pengalaman dan stimulus untuk tumbuh dan berkembang. Pengaruh keluarga terhadap perkembangan moral anak sangatlah besar. Dengan melihat perilaku orang dewasa di dalam lingkungan keluarga dimana anak tinggal, anak akan memperhatikan perilaku tersebut, kemudian menirunya dalam jangka waktu tertentu (Chawahyudi, dkk. 2005).

Pengasuhan Positif di Era digital Era digital kerap membuat orang tua sulit mengawasi anak. Orang tua yang sibuk terkadang tidak memperhatikan perkembangan dan aktivitas anak. Akibatnya pertumbuhan dan perkembangan anak tidak optimal. Banyak hal yang harus diperhatikan Orang tua terhadap anak pada era digital ini. Seiring perkembangan zaman, suka atau tidak suka orangtua tidak melulu melarang anaknya untuk berinteraksi dengan dunia digital.

Hal itu disebabkan karena memang anak sedang mengalami zaman pramillenium, di mana sekarang anak tidak hanya bersentuhan dengan digitalisasi. Akan tetapi, orang tua memang harus membiarkan anak untuk berinteraksi dengan pola perkembangan yang ada bahkan dituntut untuk melek teknologi. Namun, sebagai orang tua yang baik. Pola asuh terhadap anak tidak dapat dibiarkan begitu saja. Orang tua juga perlu melakukan pendampingan untuk menghindari hal yang tidak diinginkan. Berikut hal-hal positif yang perlu diperhatikan orang tua pada anak (Iqbal, 2018):

a. Kesehatan

Anak yang hidup di era digital banyak berinteraksi dengan dunia digital. Hal ini membuat anak jarang sekali bergerak. Anak yang sering sekali bermain gadget akan menurunkan kualitas mata anak. Tentu, anak akan mengalami kontak mata

ZURIAH : Jumnal Pendidikan Anaks Usia Dini, Vol. 1 No. 1, Mer 2020 | 31 
pada usia dini. Sebagai orang tua, anak harus di arahkan agar tidak terjebak pada dunianya sehingga mengabaikan kesehatan anak.

b. Pola tidur

Anak yang kurang tidur tentu akan terlihat lesu dan lemah. Hal ini bisa disebabkan karena anak yang terlalu asyik bermain gadget sehingga menunda waktu tidur. Orang tua perlu memberikan perhatian jadwal tidur anak jika anak mulai terlihat lemah dan tidak bersemangat.

c. Waktu

Ungkapan waktu ibarat pisau bermata dua memang benar. Anak yang terjebak dan dikendalikan teknologi tentu akan mengacaukan aktivitas belajarnya. Orang tua perlu mengawasi anak dalam memanfaatkan teknologi. Berikanlah batas waktu secukupnya untuk anak dalam berinteraksi dengan teknologi. Dengan begitu, anak mengerti bahwa waktu sangatlah berharga.

d. Ciptakan lingkungan belajar

Isilah program atau aplikasi yang berbasis pembelajaran pada setiap teknologi yang ada di sekitar anak. Misalnya gadget yang berisi aplikasi pendukung belajar anak atau tontonan televisi yang berisi pendidikan yang sesuai dengan pertumbuhan anak.

e. Kasih sayang dan perhatian

Jangan sampai orang tua membiarkan teknologi menjadi pusat perhatian anak. Keluarga adalah yang utama dalam menunjang pertumbuhan dan perkembangannya. Orang tua harus lebih sering memberikan bentuk kasih sayang dan perhatian pada anak. Anak yang memiliki rasa kasih sayang tentu didapatkan dari keluarga terutama orang tua bukannya teknologi.

Beberapa hal yang harus dilakukan oleh orang tua dalam menyikapi era yang membuat warganya konsumtif dan maju dalam melakukan pengasuhan ke anak yaitu diantaranya sebagai orang tua harus belajar dan mengenal TIK (Teknologi Informasi dan Komunikasi). Teknologi bisa diibaratkan seperti pisau dimana memiliki dua sisi yang berbeda yaitu baik serta buruknya, dan itu semua tergantung seperti apa kita mempergunakannya dan itulah hasil yang kita dapat. Kalau memang teknologi sangat sulit dijauhkan dari anak maka tidak ada salah nya kita yang mendekat dan coba 
memahami kegunaan dari internet dengan menggunakannya sebagai hal-hal positif seperti games yang mengasah otak, video-video yang merangsang kecerdasan anak dan hal-hal positif lainnya.

Direktorat jenderal pendidikan anak usia dini dan pendidikan masyarakat, mendidik anak di era digital (2016), berikut adalah beberapa cara bagaimana orang tua mendidik anaknya sesuai dengan kebutuhan anak usia dini pada era digital:

a. Memiliki kesempatan bersama yang dipahami dan di jalani anak, memonitor pelaksanaanya, konsisten menerapkan konsenkuensi atas pelanggaran dan memberikan dan memberiakan apresiasi atas keberhasilan anak dalam menjalankan kesepakatan.

b. Memanfaatkan program/aplikasi yang mendidik terkait dengan kesiapan sekolah. Misalnya pengenalan huruf, angka, dan pengetahuan dasar.

c. Memanfaatkan program/aplikasi yang mengajarkan perilaku berteman serta menghargai perbedaan dan keanekaragaman yang ada.

d. Membahas permasalahan dan perbedaan anak dengan tokoh favorit yang dilihat melalui media, dengan tujuan meningkatkan keterampilan membedakan hal yang buruk dan yang baik.

e. Menghindari tayangan program media digital yang mengandung unsur kekerasan dan seksualitas.

f. hindari tayangan program media digital yang bias akan pengenalan dan penyimpangan gender.

g. Menghindari tayangan program media digital yang menunjukkan tokohnya menyelesaikan masalah dengan kekerasan.

h. Membimbing anak mengenal mana yang fakta dan fantasi.

Setiap orang tua, memiliki gaya dan cara mendidik yang berbeda-beda dan tentunya gaya-gaya tersebut akan berpengaruh dalam perkembangan anak. Hal yang perlu diperhatikan dalam memberikan kasih sayang kepada mereka adalah tidak berlebihan dan tidak pula kurang. Berikan pelayanan dan kasih sayang secara proporsional. Ada masanya kapan seorang orang tua harus bersikap tegas dan kapan bersikap lemah lembut kepada anak. Apapun masalahnya, diharapkan orang tua tidak memarahi anak melampaui batas 
kewajaran; seperti mengumpat, menghardik dengan celaan terkutuk, apalagi sampai berlaku kasar, dan memukul anak hingga meninggalkan luka lebam di tubuhnya.

Marah bukanlah satu-satunya solusi dalam mendidik anak ketika bersalah. Selain menimbulkan efek negatif bagi perkembangan sosio-emosional dan mental anak, marah juga merupakan sifat yang sangat dilarang oleh teladan ummat akhir zaman, Rasululullah s.a.w dalam sebuah hadits, beliau bersabda, "Laa taghdlob walakal jannab" yang artinya "Jangan marah, bagimu Surga" (H.R. Ath Thabrani). Pendidikan keluarga yang baik adalah: pendidikan yang memberikan dorongan kuat kepada anaknya untuk mendapatkan pendidikan agama. Oleh karena itu ada beberapa aspek pendidikan yang sangat penting untuk diberikan dan diperhatikan orang tua, diantaranya (Elfata, 2018):

a. Pendidikan Akidah

Pendidikan islam dalam keluarga harus memperhatikan pendidikan akidah islamiyah, dimana akidah itu merupakan inti dari dasar keimanan seseorang yang harus ditanamkan kepada anak sejak dini. Sejalan dengan firman Allah yang artinya:

"Dan ingatlah ketika Luqman berkata kepada anaknya di waktu ia memberi pelajaran padanya: 'Hai anakku janganlah kamu mempersekutukan Alloh benar-benar merupakan kedlaliman yang besar'," (Q.S. Luqman:13).

Ayat tersebut menjelaskan bahwa akidah harus ditanamkan kepada anak yang merupakan dasar pedoman hidup seorang muslim.

b. Pendidikan Ibadah

Aspek pendidikan ibadah ini khususnya pendidikan shalat disebutkan dalam firman Allah yang artinya:

"Hai anakku, dirikanlah shalat dan suruhlah manusia untuk mengerjakan yang baik dan cegahlah mereka dari perbuatan munkar dan bersabarlah terhadap apa yang menimpa kamu, sesungguhnya hal yang demikian itu termasuk diwajibkan oleh Alloh,"(QS. Luqman:17).

Pendidikan dan pengajaran Al Qur'an serta pokok-pokok ajaran islam yang lain telah disebutkan dalam Hadis yang artinya: "Sebaik-baik dari kamu sekalian adalah orang yang belajar al-Qur'an dan kemudian mengajarkannya," (HR. Bukhari dan Muslim).

Penanaman pendidikan ini harus disertai contoh konkret yang masuk pemikiran anak, sehingga penghayatan mereka didasari dengan kesadaran rasional.

ZURIAH : Jumnal Pendidikan Anaks Usia Dini, Vol. 1 No. 1, Mer 2020 | 34 
Dengan demikian anak sedini mungkin sudah harus diajarkan mengenai baca dan tulis kelak menjadi generasi Qur'ani yang tangguh dalam menghadapi zaman.

c. Pendidikan Akhlakul Karimah

Orang tua mempunyai kewajiban untuk menanamkan akhlakul karimah pada anak-anaknya, dan pendidikan akhlakul karimah sangat penting untuk diberikan oleh orang tua kepada anak-anknya dalam keluarga, sebagai firman Alloh yang artinya.

"Dan sederhanakanlah kamu dalam berjalan dan lunakanlah suaramu dan sesungguhnya seburuk-buruk suara adalah suara himar,”( QS.Luqman:19)

Dari ayat ini telah menunjukkan dan menjelaskan bahwa tekanan pendidikan keluarga dalam islam adalah pendidikan akhlak, dengan jalan melatih anak membiasakan hal-hal yang baik, menghormati orang tua, bertingkah laku sopan baik dalam berperilaku keseharian maupun dalam bertutur kata.

Aqidah yang lurus, Ibadah yang benar dan pekerti yang luhur, adalah komponen dasar membangun generasi penuh berkah, generasi madaniy yang kelak dewasanya akan tumbuh menjadi pribadi yang tangguh, teguh dalam kebenaran dan tak gentar dalam menentang kebathilan. Umar bin Khatab, seorang bijak yang hidup di abad ke 7 masehi, memberikan pernyataan yang sangat terkenal: "Didiklah anakanakmu sesuai zamannya, karena mereka akan hidup pada zaman yang berbeda dengan zamanmu." Suatu pernyataan yang seolah sangat sederhana, tetapi memiliki aplikasi yang cukup rumit di dalam pelaksanaannya. Jangankan kita membandingkan dengan kondisi sekitar 14 abad yang lampau, dengan 40-50 tahun yang lampau saja dengan kondisi di Indonesia saat ini, tantangan di dalam membesarkan dan mendidik anak-anak sangatlah berbeda.

\section{KESIMPULAN}

Era digital saat ini menjadi bagian dalam kehidupan seorang anak. Hal ini di tandai dengan adanya perubahan dalam setiap aspek kehidupan anak. Era digital juga memiliki dampak yang signifikan terhadap perkembangan anak ditinjau dari berbagai aspek. Oleh karena itu, pentingnya pendekatan pada anak usia dini sebagai masa keemasan untuk bisa memanfaatkan kesempatan anak dapat berkembang secara keseluruhan baik aspek fisik motorik, kognitif, bahasa, sosial dan emosional. Salah satu hal yang menjadi perhatian orang 
tua dan pendidik anak usia dini di era digital adalah pentingnya pengenalan nilai-nilai agama, kearifan lokal, sehingga mampu membentengi anak dari pengaruh global. Bermain merupakan cara sekaligus strategi yang dapat di gunakan dalam memfilter pengaruh anak dari era digital.

\section{DAFTAR PUSTAKA}

Chawahyudi dan Damayanti D. R (2005). Program Pendidikan Untuk Anak Usia Dini di Prasekolah Islam. Jakarta: Grasindo.

Direktorat Jenderal Pendidikan Anak Usia Dini dan Pendidikan Masyarakat, Mendidik Anak di Era Digital, (2016) Kementrian Pendidikan dan Kebudayaan.

Direktorat Pembinaan Pendidikan Anak Usia Dini. (2015) Kurikulum Pendidikan Anak Usia Dini: Apa, Mengapa, dan Bagaimana. Jakarta: Kementrian Pendidikan dan Kebudayaan.

Masitoh, Strategi Pembelajaran TK, (2007), Jakarta: Universitas Terbuka.

Mukhtar Latif dkk. (2013) Orientasi Baru Pendidikan Anak Usia Dini: Teori dan Aplikasi. Jakarta: Kencana.

Sujiono, Yuliani Nurani. (2009) Konsep Dasar Pendidikan Anak Usia Dini. Jakarta: PT Indeks.

Azhma Ulya Elfata, Penguatan Peran Keluarga Dalam Pendidikan Anak di Era Digital, (https://www.dakwatuna.com/2016/03/24/79737/penguatan-peran-keluargapendidikan-anak-era-digital/\#axzz5AsK3v43W) diunduh pada tanggal 16 maret 2018

Muhammad Iqbal, Pengasuban Positif di Era digital, (http:/ /anggunpaud.kemdikbud.go.id/index. php/berita/index/20170601061529/Pengasuhan-Positif-di-Era-Digital) diunduh pada tanggal 23 maret 2018 